\title{
Craniology and the Adoption of the Three-Age System in Britain
}

\author{
By Michael A. MORSE ${ }^{1}$
}

The development of the three-age system in Scandinavia has been of great interest to historians of archaeology, but the system's spread to the British Isles has received little attention, leaving a false impression that its importance has always derived from the revolutionary methodology of C.J. Thomsen. It was not Thomsen's method of putting artefacts in a chronological series, however, that first appealed to British researchers in the mid 19th century. Instead, early British researchers, working mainly in the science of ethnology, used the system to establish a sequence of races for Britain's past based on cranial types. This initial use of the three-age system as a means of creating a racial sequence left a mark on British archaeology that outlasted even the craniological ethnology that formed its first scholarly context.

\section{THOMSEN'S ROLE}

Most accounts of the history of British archaeology highlight the development of the three-age system as one of the definitive moments in the birth of the discipline. Historical attention has focused mainly on the system's Danish originator, C.J. Thomsen, and his outspoken student, J.J.A. Worsaae, the two individuals most closely associated with the system's conception and spread. For the first generation of British researchers who adopted the system, however, the influence of Thomsen's work was indirect and surprisingly marginal. The early British prehistorians used the three-age system within an ethnological approach related more closely to Worsaae's work than to Thomsen's object-centred program. This initial use of the system in Britain, in turn, influenced the research agenda of British archaeology for a number of generations, yet it has been mostly forgotten, and Thomsen's role, which only later became important in Britain, has been somewhat exaggerated.

A key sign that Thomsen had little direct influence on the spread of the three-age system to Britain is the fact that the English translation of his work, which appears in the 1848 publication, Guide to Northern Archaeology, despite representing the 'first clear

${ }^{1}$ Department of History, University of Chicago, 1126 E. 59th Street, Chicago IL 60637, USA

Received December 1997. Accepted October 1998. statement of the concept of the three ages' (Daniel 1950,41 ), is today one of the rarest of important 19th century archaeological sources. Two of Britain's biggest libraries, the British Library and the University Library at Cambridge, do not carry the book. Though Oxford's Bodleian Library has one copy, its pages were uncut before the preparation of this article, meaning it had never before been read. It is safe to assume that the present scarcity of copies of the book reflects an original scarcity, and, added to the fact that it was rarely cited in the mid 19th century (and, indeed, has a long and continuing history of its title being cited incorrectly by people who have not seen the book), it is safe to conclude that it is unlikely that it played a central role in the adoption of the three-age system by British researchers.

The initial spread of the system to Britain was uneven, reflecting the diverse disciplinary allegiances of researchers in a time before the establishment of archaeology as a field encompassing all students of material culture. Between the first English-language references to the three-age system in the early $1840 \mathrm{~s}$ and the 1865 publication of John Lubbock's influential argument for it in Pre-Historic Times, one group of British researchers readily adopted the system, while others staunchly resisted. In order to understand why the system was such a divisive issue in the mid 19th century, and to move beyond the outdated and whiggish notion that progressive 'archaeologists' adopted it while conservative 
'antiquarians' did not, it is necessary to examine the context of the system's appearance in Britain.

In looking at the sources that preceded the 1848 English printing of Thomsen's writings and that helped create a research tradition that matured mostly independently of Thomsen's ideas, it becomes apparent that in mid 19th century Britain, the threeage system was not primarily seen as a useful scheme for the chronological ordering of ancient artefacts so much as it was seen as a way to create a racial sequence of Britain's past based almost exclusively on measurements of skulls. In the 1840s it was first adopted, not mainly by antiquarians or barrowdiggers, but by members of the emerging science of ethnology, which sought to explain human diversity through the exploration of national histories and migrations. Ethnology would later merge with the antiquarian movement to form the new discipline of prehistoric archaeology. Before further exploring the system's reception in Britain, however, it is useful to take a brief look at the context of its creation in Scandinavia.

\section{THE THREE-AGE SYSTEM IN SCANDINAVIA}

By the early nineteenth century, the idea of three ages already existed as a literary model for human development. As a theory based on extensive analyses of artefacts, however, the three-age system was born in the Museum of Northern Antiquities in Copenhagen by the 1820s (Daniel 1950, 43-4). The key Danish figure behind the system was Christian Jürgensen Thomsen (1788-1865), a numismatist whose first 20 years of curating the Danish national collections led to the 1836 publication of Ledetraad til Nordisk Oldkyndighed, translated into English along with other publications of the Royal Society of Northern Antiquaries of Copenhagen in 1848 by Lord Francis Egerton, first Earl of Ellesmere (1800-1857), in Guide to Northern Archaeology. This book described Thomsen's ordering of the collections into the three ages, based neither on a developmentalist typological scheme nor on literary evidence, but from find contexts that showed that certain types of artefacts tended to be found in isolation from each other (Gräslund 1987, 27). As a curator, Thomsen put his energy into studying the objects in the Museum with the goal that by a careful comparison and by accurately noting what sorts are generally found together, we may ascertain the order in which the successive changes took place, and thus determine the periods to which a mere inspection of the ornaments will authorize us to assign the object' (Royal Society of Northern Antiquaries 1848, 69).

This programme initially appealed not only to museum curators following Thomsen's artefact-based analysis, but also to anatomists with ethnological interests ( $c f$ Daniel 1950, 41-3). Both types of scholars relied mainly on opening barrows for their materials, the difference being whether they focused on the skeletons or on the objects buried alongside. Among curators, the Swede Bror Emil Hildebrand (1806-1884) trained under Thomsen in Copenhagen before reordering both the Historical Museum at Lund University (1830) and the Museum of National Antiquities in Stockholm (1837) according to the system. In the museum in Christiania (Oslo), Rudolf Keyser (1803-1864) was using Thomsen's system by the mid 1830s (Gräslund 1987, 14, 19-20). Perhaps the most influential of Thomsen's protégés was Jens Jacob Asmussen Worsaae (1821-1886), who worked in the Museum of Northern Antiquities with Thomsen in the $1840 \mathrm{~s}$ and readily adapted the system to ethnology. During Worsaae's nine-month tour of Britain and Ireland in 1846-7, he introduced the system to the museums in Edinburgh, Dublin, and London, though his reception was mixed (Wilkins 1961).

Among anatomists, Daniel Friederich Eschricht (1798-1863), Professor of Physiology at the University of Copenhagen, unearthed barrows to find crania, which he ordered according to the three ages. Though many of the first British researchers to use the system cited Eschricht, his work on human bones was never translated into English. Sven Nilsson (1.787-1883), Professor of Zoology and Director of the Zoology Museum in Lund, used evidence of crania, artefacts, and ethnographic parallels to study the Scandinavian Stone Age. He published his work, Skandinaviska Nordens Ur-invånare, in series from 1838 to 1843, but this was not translated into English (as The Primitive Inhabitants of Scandinavia) until 1868. According to Bibby (1956, 10), Nilsson may have come upon the idea of the Stone Age independent of Thomsen. Nilsson (1848) first presented his craniological analyses to British scientists in 1847 , when his paper, 'On the Primitive Inhabitants of Scandinavia', was read to the British Association for the Advancement of Science. In 1842, Anders Retzius 


\section{M. Morse CRANIOLogy \& THE ADOPTION OF THE 3-AgE SYSTEM IN BRITAIN}

(1796-1860), also a Swedish anatomist, developed the enormously influential cephalic index, which soon replaced the facial angle, the index developed by the Dutch anatomist Pieter Camper in the 1760 s, to become the leading racial index in European craniometry. The cephalic index gives a relative measure of head form, separating generally brachycephalic (short-headed) from dolichocephalic (long-headed) types. According to Nilsson (1868, 107), it constituted the major step forward that established the ethnological potential of craniometry, as it provided a mathematical means of correlating different head sizes with the three ages. Retzius (1847) presented his work to the British Association in 1846 in his paper, 'On the Ethnographical Distribution of Round and Elongated Crania'.

\section{THE INTRODUCTION OF THE THREE-AGE SYSTEM INTO BRITAIN}

Though Thomsen had developed the three-age system by the $1820 \mathrm{~s}$, none of its Scandinavian advocates published English descriptions of it until the late 1840 s. And by the late 1850 s, so few important Danish works were translated that John Lubbock, one of the key figures behind the synthesis between ethnology and antiquarianism, felt impelled to learn the language (Lubbock 1865, vii). Before this time, knowledge of the system filtered to a handful of British researchers through personal connections, mostly through the Royal Society of Northern Antiquaries of Copenhagen. David Laing, an officer in the Society of Antiquaries of Scotland from the 1820s, had personal contacts in Denmark and initiated a correspondence with the Danish Royal Society in 1829 (Ash 1981, 92-3). Yet the Scottish Society adopted the system neither in its displays nor in its publications until Worsaae's visit in 1846 made an impression on Daniel Wilson. Thomsen himself had written a letter about the system to the Society of Antiquaries of London in 1828, but it received little notice (Evans 1956, 230). The Earl of Ellesmere was a British member of Denmark's Royal Society and read a very limited description of some aspects of the system in a communication from the Society in 1836, but waited 12 years to publish Guide to Northern Archaeology (Royal Society of Northern Antiquaries $1836,18 ; 1848, \mathrm{xvi})$. And on the first anniversary of the Ethnological Society of London in 1844, the
Secretary, Richard King, indicated that the Society in Copenhagen was engaged in 'highly-interesting' activities $(1850,20)$, but he did not mention the threeage system specifically.

Whether on account of the system's initial lack of appeal or its difficulty in reaching a British audience, Thomsen's writings had little influence in Britain. Instead, word of the system spread mainly through his more ethnographically minded followers. When Guide to Northern Archaeology was finally published in 1848, most British antiquarians and ethnologists were already familiar with the three ages.

One of the earliest published references to the three-age system in Britain came from James Cowles Prichard (1786-1848), who had established a reputation as the leader of ethnology in Britain through his career-long endeavours 'to trace the affinities of different nations' (Prichard 1813, 3; Stocking 1973, ix). Prichard's incorporation of the three-age system into his work, first evident in 1841 and explicit in 1843, occurred in parallel with the founding of the Ethnological Society of London (1843), the push to give ethnology its own section within the British Association, and the self-conscious development of ethnology as an independent field.

In 1841, in the European volume of the third edition of his Researches into the Physical History of Mankind, Prichard quoted at length from Eschricht's work, which had appeared in a Danish journal called Dansk Folkeblad, and he included drawings of skulls in Eschricht's collection among the plates (Fig. 1). While Prichard did not mention the three ages specifically at this point, his quotation of Eschricht certainly indicated the chronological potential of assigning excavated tumuli to various ages depending on the composition of the objects found with the skeletons:

in the most ancient times the [burial] ornaments were generally of amber, and the weapons and implements of stone or bone; seldom, perhaps never, of metal. This circumstance furnishes the ground for distinguishing the sepulchral remains of the northern land as belonging to different chronological eras (Prichard 1841, xviii, emphasis in original).

Because the three-age system spread through ethnology, which was more oriented towards anatomy than was antiquarianism in Scandinavia, it soon became linked with the growth of craniology in 


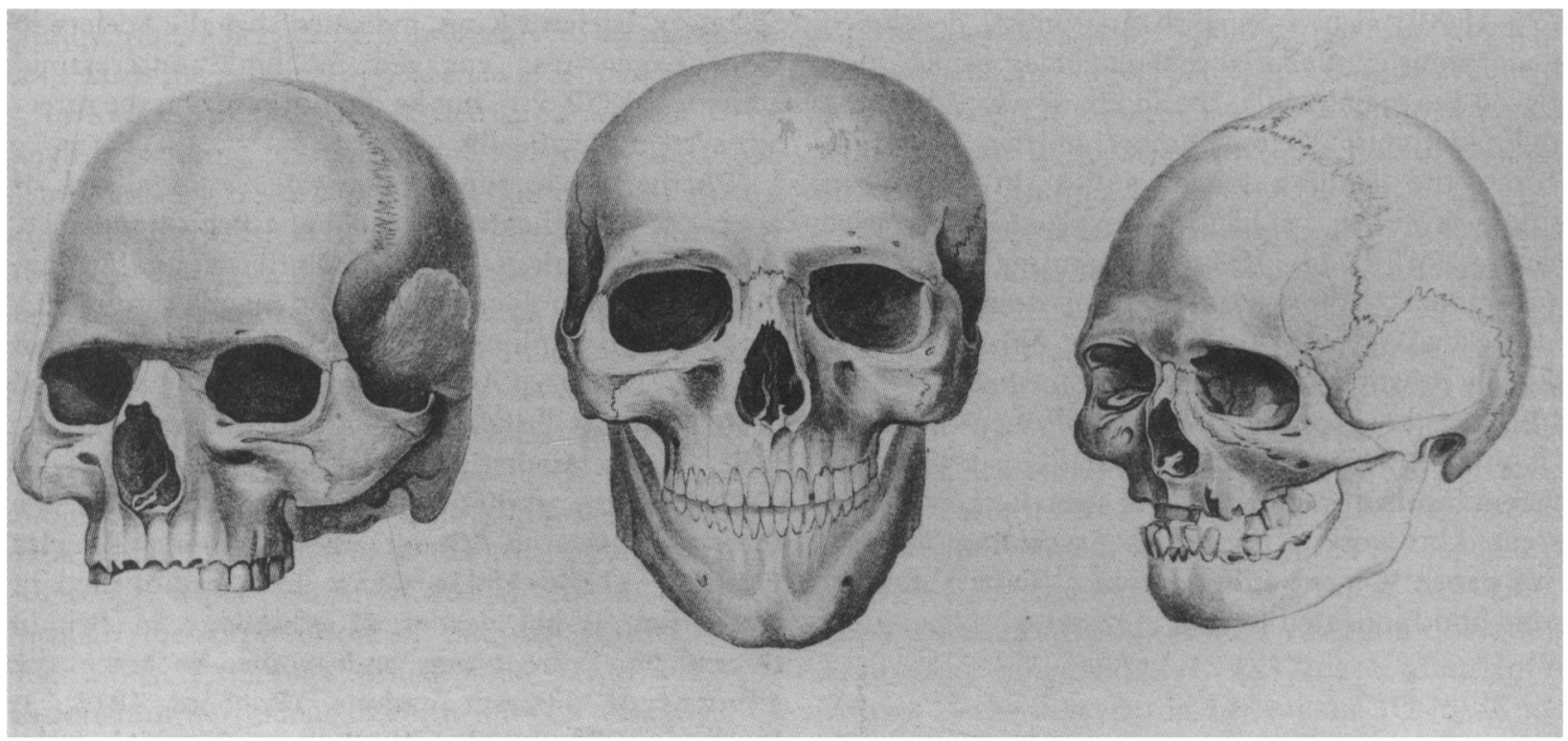

Fig. 1

'Specimens of the Crania of the Oldest Races of Europe' from J.C. Prichard's Researches into the Physical History of Mankind, vol. 3 (1841) and The Natural History of Man (1843)

British ethnology. In the same volume where he first showed familiarity with the three-age system, Prichard expressed increased optimism about the potential contributions of craniology to ethnology. In both the first and second editions of Researches, Prichard had paid careful attention to skull shape, calling it the 'most important instance of diversity in the human form' (Prichard 1813, 46; 1826, 158). Yet in neither case did he consider a program of tracing racial movements through the use of excavated crania. Despite Prichard's new-found use of craniology in the third edition, however, he retained his long-standing reliance on language history as his primary source of evidence and limited his discussion of British skulls to a single paragraph, in which he described ancient British skulls as having narrow foreheads (Prichard 1841, 200).

His limited use of craniological evidence, however, derived only partly from this preference for linguistic and historical data. He did not yet have access to a significant number of crania and lamented the lack of a 'national collection of the sepulchral remains of our ancestors' (Ibid., xxi), as existed in Scandinavia, where Retzius had access to hundreds of skulls, and in Ireland, where William Wilde was setting out on a program of studying ancient Irish crania (see below).
In the weeks before his death in 1848 , Prichard told Thomas Hodgkin at a meeting of the Ethnological Society that he was hoping to fill this gap and was planning a large-scale survey of ancient British crania (Hodgkin 1850, 204).

In 1843, Prichard further explored the implications of Eschricht's work in The Natural History of Man, in which he presented his results to a more general readership. Here, Prichard $(1843,191)$ described Eschricht's work as that of fitting burial evidence into the three-age framework, possibly marking the first published reference to the Danish system in English. By this point, the Scandinavian craniological approach to ethnology had produced results significant enough that Prichard felt the need to address in detail their implications for his model of the peopling of Europe:

The purpose for which I have been induced to offer these observations is to point out the series of osteological remains which may be established by means of them. There seems to be good reason to believe that, by a collection of skulls and skeletons from these different sets of barrows, an historical series may be established, each set displaying the remains of the races of people by whom they were erected. (Prichard 1843,192 ) 


\section{M. Morse CRANiology \& THE ADOPTION OF THE 3-AGE SYSTFM IN BRITAIN}

When Prichard began addressing these results in the third edition of Researches, he had become receptive to the notion that there were races, which he termed collectively as Allophylians, that reached Europe before the Indo-Europeans $(1841,8)$. This idea - one of the first proposals that Europe had received more than one major wave of migration from the assumed point of human origin in the Near East - had been given currency by the Danish philologist Rasmus Rask (1783-1832) upon recognising that Finnish and Basque were non-Indo-European languages. In 1844, Prichard published a paper, 'On the Crania of the Laplanders and Finlanders', supporting the notion that such peoples had skull forms different from later European types. Yet he never accepted that Allophylians preceded Celts - who had been widely taken to be the first inhabitants of western Europe - in Britain, despite the fact that he considered Britain's earliest inhabitants to have had 'something of the Mongolian or Turanian form of the head' $(1841, \mathrm{xx})$. This loyalty to his own long-standing theory of the peopling of Britain, in light of the new craniological evidence, derived from his primary reliance on linguistic data, for he found no evidence for pre-Celtic languages in Britain.

In the early 1840s, Prichard was the main British outlet for the ideas of Scandinavian ethnologists, who did not visit British scientific meetings or send English versions of their work to Britain until 1846. The more limited role he ascribed to craniology, and his reluctance to accept the existence of races other than the Celts in pre-Roman Britain, held sway in British ethnology in that time. The one major exception to this situation was the Irish physician and ethnographer Sir William Wilde (1815-1876), the father of the famous author, and the husband of a prominent member of the Young Ireland movement. Wilde entered ethnological circles through the British Association, where he contacted Prichard as early as 1839 about skulls he had examined on the circumMediterranean excursion that led to his best-selling travel book, The Narrative of a Voyage (1840, $345-57)$. In the 1840 s Wilde turned his attention to ancient Irish skulls, leading to an important speech in 1844 on ethnology to the King and Queen's College of Physicians in Dublin. Later, he incorporated this speech into an ethnological chapter in his Irish travel book, The Beauties of the Boyne, and Its Tributary, The Blackwater (1849), which was also a best-seller and reached the attention of many more ethnologists than did his speech.
After Wilde became interested in ancient skulls on his Mediterranean trip, he contacted Retzius and Eschricht, 'two of the most distinguished northern philosophers', to discuss his views on ancient Irish examples and he enlisted a colleague to translate some of the articles of the Scandinavian anatomists (Wilde 1844, 247). Following his contact with Prichard and the Scandinavians Wilde became the second British researcher to utilise the three-age system as a part of:

the science of Ethnography, or the natural history of man, including his physical character - his form and stature - the colour of his skin - his hair and his complexion - his physiognomy - his habits and moral condition - together with his geographical distribution, but more particularly than all the rest, the form of his skull. $(1844,232)$

Though Wilde saw physical ethnology as just one of four avenues for investigating Ireland's past - the other three being linguistics, the study of art and architecture, and history - he found it to be the most reliable source of evidence.

Combining the system with what he knew from early Irish literature, Wilde argued that Ireland's first inhabitants were Stone-Age 'Firbolgs', a 'simple pastoral people' who, following Rask's Finn hypothesis, were non-Indo-European (1844, 233; 1849, 218-20). The Firbolgs were then replaced by a Bronze-Age 'globular-headed, light-eyed, fair-haired, Celtic people', known as the 'Tuatha De Dannan', who, in turn, brought metal technology to Scandinavia (1844, 233; 1849, 221-2, 231, 238). Wilde's sequence ended at AD 900 with the start of the Irish Iron Age thanks to the arrival of northern races. With this argument, Wilde became the first ethnologist in the British Isles, not only to address the results of the Scandinavian system, but to base his racial sequence on it. Wilde continued to use the three-age system as the basis for his investigation of Ireland's past when he prepared a catalogue of the Museum of the Royal Irish Academy for the 1857 meeting of the British Association in Dublin (Wilde 1857; 1861, 350-3).

Wilde's 1844 speech, presented to Dublin physicians and published in a local periodical, had little immediate impact on the spread of the three-age system. Perhaps the most significant catalyst for the idea's spread was Worsaae's 1846-7 tour of the British Isles, when he explained his brand of ethnology to 
museum curators and antiquarian society members. It is only during Worsaae's visit that the system gained recognition in Britain's two national archaeological societies, the Archaeological Institute (Thoms 1846; Du Noyer 1847, 1) and the British Archaeological Association (Croker 1847, 333; Anonymous 1848, 154-5).

In 1843, under the patronage of the Danish royal family and as an assistant to Thomsen, Worsaae had written Danmarks Oldtid, an ethnological examination of Denmark's past structured around the threeage system. Worsaae shared Prichard's distrust of 'uncertain and imperfect' historical sources (1849, 121), which, in any event, were not of much use for learning about the ancient past of a part of Europe virtually untouched by classical civilisations. Instead of turning to languages as an alternative, however, Worsaae proposed, 'it is clear that we are enabled, by means of the antiquities and barrows, to form much clearer ideas, as to the peopling and civilization of Denmark, in primeval times' $(1849,121)$.

In the spring of 1846, King Christian VIII, who had commissioned Danmarks Oldtid, asked Worsaae to visit Great Britain and Ireland in order to see what Danish monuments might be found there. Though Christian VIII did not live to see Worsaae fulfil this request, his successor Frederick VII, himself an avid archaeologist (Bibby 1956, 94-109), supported the idea, and by the autumn, Worsaae had arrived in Britain. At this point Danmarks Oldtid had been translated into German. To Worsaae's surprise, when he reached Britain, he learned that William Thoms (1803-1885) - a member of the Archaeological Institute, to which Worsaae (1847b) presented a paper on silver antiquities during his visit - had translated the German version into English. In 1846, the same year that he coined the word 'folk-lore' (Dorson 1968, 75; Stocking 1987, 55), Thoms wrote a review of the German edition of Danmarks Oldtid for the Archaeological Journal, in which he celebrated Worsaae for allowing antiquarian researchers to divide barrows among various races and for showing 'the gradual progress of civilization' $(1846,292)$. Thoms' translation, which he had enlarged from the original, was published in 1849 as The Primeval Antiquities of Denmark. Daniel called this book one of 'the most important archaeological works produced in the first half of the nineteenth century', for it 'laid down the principles of prehistoric archaeology' in its application of the three-age system
(1950, 45-6). By the book's publication in 1849, however, Worsaae's impact was already felt throughout the British Isles.

Worsaae's $1846-7$ visit brought him in personal contact with the major museums and archaeological societies in Edinburgh, Dublin, and London. Though he only spoke about the three-age system in two formal lectures, both to the Royal Irish Academy (RIA), he was able to win converts through informal discussions (Wilkins 1961). In his speeches, he presented his work, in name and method, as part of ethnology, 'a most important branch of science' (1847a, 311). Like Prichard, he contrasted his new approach with a reliance on written records. And, as in Primeval Antiquities, he replaced Prichardian linguistics with the idea, 'it has become possible to enter upon an entirely new inquiry into the history of the earliest state of the European nations, by means of the antiquities alone' $(1847 \mathrm{a}, 328)$. Thanks in large part to Worsaae's influence, this new kind of ethnology, revolving primarily around antiquities and the three-age system, began to form a challenge to Prichard's linguistic ethnology and became the basis for the emerging discipline of archaeology.

As ethnologists began to incorporate the evidence of antiquities, crania became increasingly important for describing and understanding past races. Worsaae argued for craniological ethnology both in his second speech to the RIA and in Primeval Antiquities. In this speech, he outlined his three-age understanding of Danish and Irish antiquities. Describing the Stone Age, he said:

It is only through a careful examination and comparison of the skeletons and skulls found in the tumuli just mentioned, that we can get information concerning the races to which this aboriginal people belonged. (1847a, 329)

In Primeval Antiquities, he reiterated this position. In attempting to figure out which race was represented by the Stone Age, he lamented the dearth of craniological evidence, which he thought would provide a definite answer with the collection of more data $(1849,131-3)$.

For both Worsaae and Nilsson, the Stone Age was the period that most needed craniological evidence in order to be incorporated into an ethnological history of European races. Until the mid 1850s, when Worsaae began to regard the Iron Age in northern 


\section{M. Morse CRANIOLOGY \& THE ADOPTION OF THE 3-AGE SYSTEM IN BRITAIN}

Europe as starting shortly before Roman times, he saw iron technology as something that became widespread only after the fall of Rome, meaning that he took the 'barbarian' peoples in classical texts to be part of Bronze Age Europe (Worsaae 1847a, 331; 1849, 140; Klindt-Jensen 1975, 73; Gräslund 1987, 49). For the Bronze and Iron Ages, therefore, he could more easily turn to historical and linguistic sources.

In Worsaae's interpretation, the intrusion of new races, either through replacement or intermixing, was the primary explanation for the transitions between the three ages:

All facts, for instance, seem to shew that Europe was not peopled at once, by a race of mankind who bore in themselves the germ of all future progress, but that this race gradually received the addition of others who continually supplanted the former, and laid the foundation for a more advanced civilization. (Worsaae $1849,134)$

At the same time, Worsaae did not think that any particular race was necessarily responsible for the start of a new age all over Europe. In the case of the Bronze Age, for example, he felt that this was when the Celts arrived in Western Europe, but through a study of runic inscriptions in Denmark, he concluded that Bronze Age Denmark was home to a Gothic race, rather than a Celtic one (Worsaae 1849, 142-3). Worsaae saw the Celtic race as most prominent in Ireland $(1847 \mathrm{a}, 343)$.

By 1847 , when the three-age system had become well known among British ethnologists and a number of Scandinavian researchers had either visited Britain or published English versions of their work, Prichard finally tempered his almost career-long confidence that the Celts were the first Britons, highlighting the impact of the Scandinavians' arrival. Under the growing weight of craniological evidence that Stone Age Europe was inhabited by non-Indo-Europeans, Prichard wrote, 'Whether the oldest tombs were the sepulchres of a Celtic race, is a question not yet decided' (1848, 237). And, in discussing the possibility that Europe was first peopled by 'UgroTartarians' (part of Prichard's Allophylians), he wrote:

I must here observe that many modern writers seem disposed to believe that the Celtic nations, at least the original people of the British Isles whose descendants are the Welsh and Irish, were in part of Finnish or Lappish descent and sprang from a mixture of this race with a tribe of Indo-European origin. $(1848,246)$
It is notable that, in the last year of Prichard's life, he recognised the legitimacy of this rival theory, which gave more weight to craniology than to linguistics. Prichard's apparent loss of surety regarding the Celtic origins of Britain, and of the superiority of linguistic data over craniological data, can be attributed to the increased contact in the late 1840 s between British and Scandinavian ethnologists, as well as to the growing influence of craniology both on the Continent and in America (Stocking 1987, 67).

\section{THE SPREAD OF THE THREE-AGE SYSTEM IN BRITAIN}

At the end of the 1840s, Daniel Wilson (1816-1892) started the first large-scale research project in Britain using Scandinavian craniological ethnology and the three-age system. Wilson joined the Society of Antiquaries of Scotland shortly before Worsaae's 1846 visit and was appointed Secretary soon after. Wilson's response to Worsaae was swift. In 1849, he organised his Synopsis of the Museum of the Society of Antiquaries of Scotland according to the system, with both the Stone and Bronze Ages - the two preRoman periods according to Worsaae - labelled as Celtic. In 1850, when Wilson (1851b) presented his work to the British Association during its summer meeting in Edinburgh, he had completed his conversion to the Scandinavian model, in which nonIndo-Europeans were the first inhabitants of Europe.

The title of Wilson's paper, 'Inquiry into the Evidence of the Existence of Primitive Races in Scotland prior to the Celtae', clearly reflected the influence of the Scandinavian approach for his picture of Britain's past. The paper was written as an argument, not just for the existence of pre-Celtic inhabitants of Britain, but for the very practice of craniological ethnology:

It is to be regretted that this branch of physical archaeology has heretofore been so little esteemed in this country in comparison of the contributions afforded by philological researches to ethnology. (1851b, 142)

His regret was echoed by other British Association ethnologists, who 'repeatedly commended' his results 'as the first steps in an entirely new course of scientific investigation' (Anonymous 1850, 908). 
In outlining his evidence, Wilson mainly followed Nilsson's work and added his own data to illustrate the particular sequence of races in Scotland. Departing from Nilsson's (1848) Scandinavian model of a brachycephalic race followed by a dolichocephalic one, Wilson argued that the earliest Scots were 'Cymbocephalic' - meaning 'boat-like' - and were followed by a brachycephalic race, though larger-brained than the Scandinavian brachycephalic race (Wilson 1851b, 143). Nilsson and Wilson agreed that the next race in the sequence, which arrived with bronze technology, had 'the true Celtic type of cranium' and exhibited 'an intermediate form, shorter than the true Dolicho-cephalic, and longer than the Brachy-cephalic' (Ibid.). While Wilson interpreted the sequence of the three ages as representing a progression in 'the social state in the British Isles', he did not subscribe to Worsaae's idea that race replacement was necessary to bring change and did not prejudge the question of whether technological innovations came about 'by the gradual improvement of the aboriginal race, or by the incursion of foreign tribes' (Ibid., 144).

A year after introducing his craniological study to the British Association, Wilson (1851a) published The Archaeology and Prehistoric Annals of Scotland, the first 'synthesis of prehistoric times in the English language' (Trigger 1989, 82), in which Wilson classified Scotland's past into four ages: Stone, Bronze, Iron, and Christian. Unlike Wilde's (1849) shorter book, The Beauties of the Boyne, which had just one ethnological chapter, Wilson's book was a monumental study, entirely dedicated to outlining and illustrating the past peoples of Scotland. The importance of this book for the history of archaeology has generally been understated, and it is usually noted simply for its relatively early use of the three-age system and for its introduction of the word 'prehistoric' into archaeological literature (eg, Daniel 1950, 86; Trigger 1989, 82-3). With Prehistoric Annals, Wilson set out to draw together various research traditions - the county history genre epitomised by Sir Richard Colt Hoare's (1812; 1821) The Ancient History of Wiltshire, object-based antiquarianism, and linguistic and physical ethnology mixed with historical and biblical analyses - to address the peopling of Scotland (Wilson 1851a, xii-xiv, 1-5, 43). In his vision of how these traditions fit together, antiquarian objects were useful in providing a context for interpreting human skeletal remains in order to construct, with the help of written sources, a racial sequence. This vision did more than establish a methodology for the 'scientific antiquarianism' he termed archaeology (Ibid., 5). It defined the field's central subject - which was the time period that had previously been subsumed under the general term 'Celtic'.

Wilson was aware of the novelty of his project and tried to justify its usefulness for ethnology. He couched the argument for his brand of archaeology in terms of the general struggle in ethnology to gain scientific recognition in the form of a section at the British Association (1851a, xii-xiii; Stocking 1987, 245). Archaeology for Wilson deserved similar recognition for it 'yields the most trustworthy, if not the sole evidence in relation to extinct branches of the human family' (Ibid., xiii). Wilson went on to set out his argument for the central importance of 'Physical Archaeology' in his project:

To this branch of evidence it is probable that much greater importance will be attached when it has been thoroughly investigated, since to it we may look, with considerable confidence, for a distinct reply to the inquiry, which other departments of archaeological evidence suggest as to the existence of primitive races in Britain prior to the Celtae. (1851a, 12)

Unlike many of the Scandinavian ethnologists, Wilson was an adamant monogenist and consequently allowed more room for independent development within each race. He argued that Stone Age people:

were abundantly capable of civilization, and possessed a cerebral capacity fully equal to that of nations which have carried the practical and decorative arts far in advance of a more archaic period. (Wilson 1851a, 183)

According to Wilson's sequence, when the Celts arrived in the Bronze Age, the Allophylians had already begun working with bronze technology (Ibid., 343). As he separated the questions of racial sequence and technological development, Wilson nevertheless saw intermingling with new races as the cause of Scotland's distinctive sequence of crania, which he correlated with technological epochs (Ibid., 229-32).

As Wilson's work gained recognition, the growth of 'physical ethnology' was starting to influence antiquarian researchers. This trend is well illustrated by the changing ideas of Thomas Bateman. Bateman 


\section{M. Morse CRANIOLOGY \& THE ADOPTION OF THE 3-AGE SYSTEM IN BRITAIN}

(1821-1861) was one of the first in the long tradition of barrow-digging to turn to craniological evidence (Marsden 1983, 50), but only after he felt the influence of Scandinavian craniological ethnology and British phrenology. Before turning to crania, Bateman had worked within the county history genre in his Vestiges of the Antiquities of Derbyshire in 1848. In this volume Bateman described the peopling of Britain as 'a mystery upon which conjecture or theory can throw but little light', and, instead of offering an archaeological theory, put forth a literary version of events, which he drew from 'the opinions of scholars and chronologists' who connected the Celts through an ancestral tree back to Noah $(1848,1)$. Bateman's approach had changed radically by the 1861 publication of his follow-up book, Ten Years' Diggings in Celtic and Saxon Grave Hills, in which he criticised Colt Hoare for neglecting 'ancient Celtic crania' and looked to ethnological archaeology as a way to study the 'possibly pre-Celtic' population of Britain (1861, preface: $v$, introduction: ii-iii).

Between 1848 and 1861, Bateman adopted the three-age system and started to treat crania as a valuable source of evidence. From the many barrows Bateman had opened, he created a private museum which was well known to members of the various archaeological societies. In his 1855 museum catalogue, Bateman divided his Britannic Collections into a 'Celtic Period' of 'Stone and Bronze', a 'Roman and Romano-British Period', and a 'Teutonic or Iron Period', before the more recent historical periods. While this periodisation differed slightly from Wilson's, it shared the use of the three-age system as the key to creating a sequence of cranial types.

The shift in Bateman's thinking probably occurred in 1849. In August of that year, Joseph Barnard Davis (1801-1881) visited Bateman's museum and noticed that he had collected a large number of ancient skulls (Davis \& Thurnam 1865, preface; Stocking 1987, 66), probably comprising one of the largest such collections in Britain at the time. In the years after 1849, Bateman and Davis collected skulls together, providing material for Bateman's Ten Years' Diggings and Davis' and Thurnam's (1865) Crania Britannica.

Growing interest in skulls was also fostered by the phrenological movement, whose influence was manifest in the subtitle of the short-lived (1848-9) Ethnological Journal: A Magazine of Ethnography, Phrenology, and Archaeology, Considered as Elements of the Science of Race (Cooter 1989, 128) and which captured the attention of Davis early in his career (Stocking 1987, 66). In fact, the very word 'craniology' was often taken to be synonymous with the phrenological inquiry into a person's character by means of examining head shape (Cooter 1989, viii). Though it was waning by the 1840 s, phrenology fit well with Scandinavian ethnology in that both disciplinary traditions sought to identify the skull types of various races (Stepan 1982, 23). George Combe (1788-1858), a leader of the phrenological movement, thought that phrenology 'holds good in the case of nations as well as of individuals' and presented a sample of European crania in his synthesis of the field (1843, 334, 356-71). Aside from Bateman's collection of ancient skulls, most British skull collections in the 1840 s, including one in Edinburgh that provided Wilson with most of his material, were related to phrenology (Goyder 1845, 60-1).

Davis and Bateman were quickly joined in their research into British crania by the physician John Thurnam (1810-1873), who dated his interest in archaeology to seeing two ancient skulls in 1849 in a display at the hospital where he worked (Bibby 1956, 226) and who was familiar with phrenology through his work on the insane. Both Thurnam and Davis were members of the Archaeological Institute and used the society as a forum to further their craniological programme. In 1850, Thurnam presented a paper to the Institute praising the success of Worsaae's approach to the early peopling of Europe and encouraging British researchers to collect crania as well. Davis $(1855 ; 1856)$ followed this with a paper to the British Association in 1854 and one to the Archaeological Institute in 1856, the same year that their joint effort, Crania Britannica, began publication. In his papers, Davis argued that physical characteristics constituted a better source of evidence than did languages in ethnology and that the three-age system provided the key for studying crania (Davis $1855,127 ; 1856,316)$.

With financial help from the Royal Society, Davis and Thurnam published Crania Britannica in six installments from 1856 to 1865 . While the study included only 56 skulls, which was not substantially more than the 39 Wilson examined, it was noteworthy for including life-size illustrations with detailed descriptions of each skull (Fig. 2). With two authors working in parallel and publication spread out over a decade, Crania Britannica did not result in 


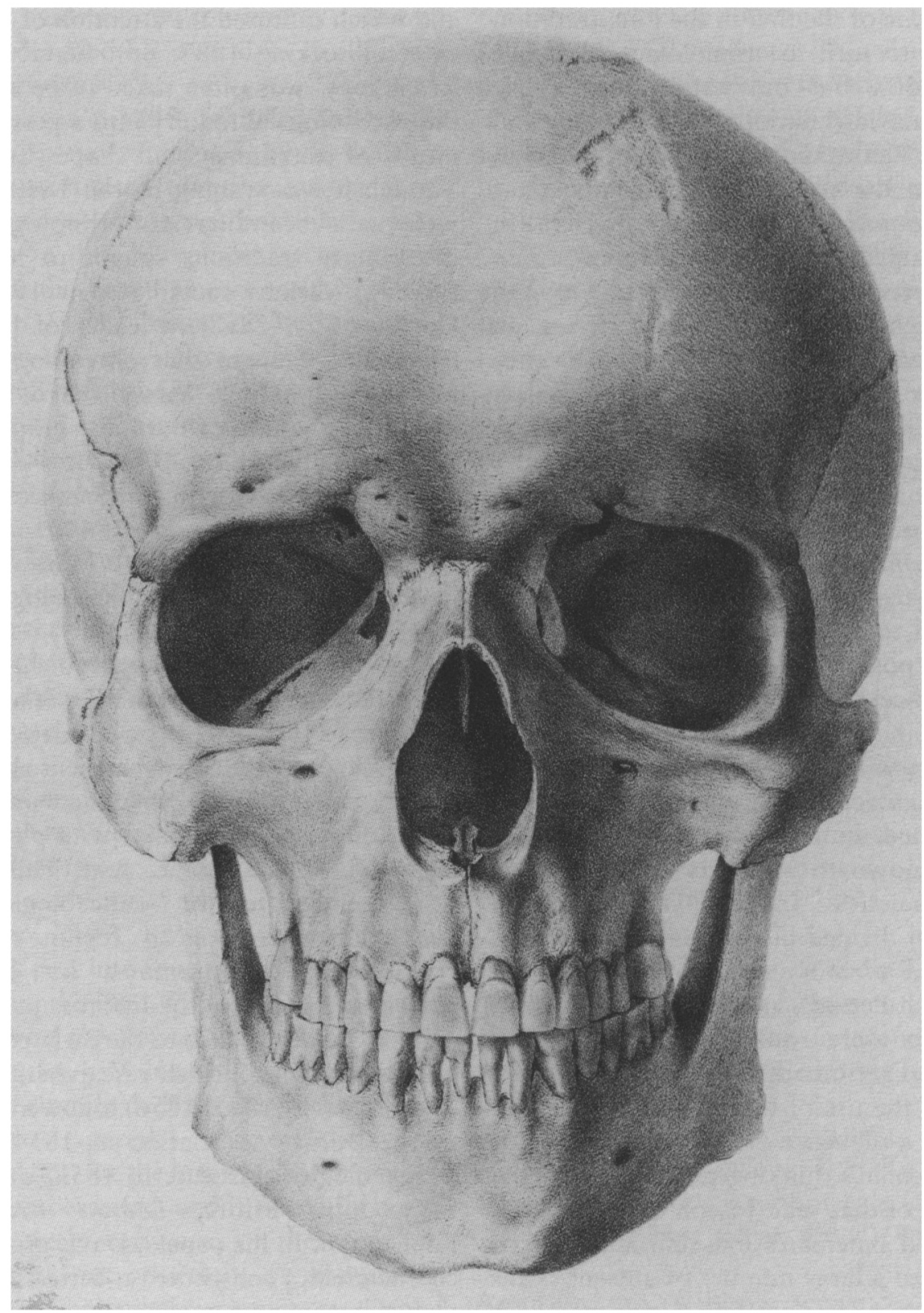

Fig. 2

A 'fine example of the typical form of the ancient British cranium' from Crania Britannica (Davis \& Thurman 1865: plate 3; emphasis in original)

any firm conclusions about the ancient British past. Davis' review, in chapter 2, of what the day's major ethnologists had to say about Celtic crania, made it clear that this lack of a conclusion also derived from a general disarray in craniology. Though the authors viewed skull shape as "not transmutable in the different Races' (Davis \& Thurnam 1865, 2), there was no agreement among ethnologists as to which shapes corresponded with which races. Davis tentatively suggested that long barrows tended to contain longer, dolichocephalic, crania, but with the qualification that Britain's racial past was always 


\section{M. Morse CRANIOLOGY \& THE ADOPTION OF THE 3-AGE SYSTEM IN BRITAIN}

somewhat mixed and that deformities confused the picture (ibid., 229). Thurnam, meanwhile, had more confidence in the notion that a dolichocephalic Stone Age race was replaced by a brachycephalic Bronze Age one, and presented this idea - that long barrows, the earlier interment class, corresponded with long heads and round barrows, the latter, with round heads - to the Anthropological Society of London (ibid., 1865,230 , plate 59, 6; Thurnam 1865). In light of the confusion, both authors agreed that further study and collection were necessary, with the goal being the identification of examples of pure types.

\section{DEBATES IN ETHNOLOGY}

Despite the growing interest in physical ethnology and the three-age system among antiquarians in the 1850 s, there was a large degree of resistance to these methods. The system's detractors, led by Thomas Wright (1810-1877), belonged to the group Van Riper labelled 'historical archaeologists' $(1993,16)$. They opposed the idea of the three ages on the grounds that it was a generalisation not supported by enough evidence (Wright 1852, vii). Aside from being committed Baconians (Van Riper 1993, 41-2) who viewed archaeology as best used 'hand-in-hand with history' (Wright 1852 , viii), the detractors were probably hesitant to adopt the system because both Thomsen's and Worsaae's published accounts of the system were brief, supported by no more than cursory evidence, and appeared more as assertions than conclusions drawn from extensive examinations of finds (Gräslund 1987, 20). Until the publication of Lubbock's Pre-Historic Times in 1865 , there was not a sufficiently strong argument for the three-age system in print for it to capture the overwhelming support of antiquarians (cf. Daniel 1950, 77-85). In the intervening time, the system's adherents and detractors both thought of their work as relevant to ethnology (eg, Wright 1855), the central difference being their varying emphasis on historical and craniological evidence. In other words, until the publication of Lubbock's Pre-Historic Times, support for the three-age system was correlated more with interest in craniological ethnology than with interest in studying artefacts in order to place them in a chronological sequence.

Another key factor in the variable reception to the three-age system related to differing interpretations of the capabilities of pre-Roman Britons. While Wilson saw all of Scotland's inhabitants since the Stone Age as 'abundantly capable of civilization' (1851a, 183) and while the Scandinavian ethnologists put the Celts in the Bronze Age, Wright characterised Celts as 'serfs, without civil influence or even civil rights; the mere slaves of superior orders' $(1852,4)$. The 'historical archaeologists' tended to dismiss the Celts partly because relatively few historical sources documented that era and they focused their energies on later periods, especially Roman and Saxon.

By the 1860s, when craniological ethnology had grown in prestige in the Ethnological Society, another collector of crania, the polygenist Robert Knox (d. 1862), had applied Wright's view of Celts to craniology. While Wright's group challenged craniological ethnology by arguing that it had no basis, Knox and his followers posed a challenge to the emerging discipline by carrying the racial approach too far. Knox was primarily interested in colonial peoples and discussed their subjugation and slavery in terms of their supposed biological inferiority. $\mathrm{He}$ treated the 'Irish Celts' as inferior colonial subjects and attributed the anti-British agitation of the $1840 \mathrm{~s}$ to the irreconcilability between Celt and Saxon (Knox 1850, 324; Hunt 1868; Stepan 1982, 100). While Knox's work never entered mainstream ethnology, his fervent polygenism tapped into the existing sympathies of some ethnologists and archaeologists. Knox's work had an influence on James Hunt, who precipitated a bitter split between liberal-minded ethnology and his own racialist physical anthropology (Stocking 1987, 246-54). Hunt's group broke from the Ethnological Society in 1863 to form the Anthropological Society of London.

Wilson criticised the racialist excesses of Knoxian craniology, but this did not temper his faith in 'physical ethnology', which, by the 1860 s, had 'received an amount of attention in some degree commensurate with its importance' $(1863,236)$. He felt the growth in craniology was a vindication of his radical proposal in 1850 that there had been a preCeltic race in Britain. Wilson still believed, 'that the form of the human skull is essentially distinctive of race', with the difficulty lying in identifying 'the ethnical significance of form, proportions, prognathism or orthognathism, and other characteristic diversities' $(1865,57)$, a difficulty that resulted in various researchers coming up with conflicting definitions of the Celts and other races. 
Under the influence of the phrenologist Gustaf Kombst, Wilson turned to measuring living people's head sizes as a way to address the problem of assigning races to ancient skulls, which could possibly represent mixed races. From his base in Canada, where he settled in 1853, he undertook a survey of hat sizes among both French and British immigrants and worked out whether they were Celtic or Saxon on the basis of their last names. This survey led him to believe, contrary to the opinions of Nilsson and Davis, but in concert with others, that Celts are generally dolichocephalic $(1865,72-84)$. The lack of consensus in the 1860 s about which cranial measurements corresponded to the different races did nothing to detract from the optimism ethnologists had about the usefulness of their approach, and many like Wilson continued to develop innovative methods to solve the confusion.

\section{LUBBOCK AND THE PREDOMINANCE OF CRANIOLOGY}

As Wilson's changing views illustrate, through the use of innovative methods, craniology in the $1860 \mathrm{~s}$ survived both the elusiveness of identifying racial types and the possible stigmatisation of craniology as racist science, thanks to the growing prominence of Hunt's anthropological program. And despite the departure of the more fervent racialists into the Anthropological Society, craniology remained an important aspect of the activities of the Ethnological Society. John Lubbock (1834-1913), the evolutionist and neighbour of Charles Darwin, became President of the Ethnological Society upon Hunt's departure (Stocking 1987, 150-6, 248-9), just two years before the publication of Pre-Historic Times, which combined Scandinavian three-age craniological ethnology with the new understanding of the great antiquity of humanity into a programme of prehistoric archaeology (Trigger 1989, 114-5; Van Riper 1993, 199-201). While Lubbock's use of craniology did not involve the racialism of Knox and Hunt and lacked the 'moral' dimension of their anatomical program (Richards 1989), his emphasis on using ancient crania to understand past racial sequences became a firm part of mainstream ethnology thanks to the unmatched preeminence of Pre-Historic Times in the next half century (Trigger 1989, 114).

Next to the three-age system, the establishment of human antiquity in $\mathbf{1 8 5 9}$ provided the key impetus to
Pre-Historic Times. This revolution in thinking about the age of humanity had a tremendous impact on broader ethnological issues and brought about the final collapse of the biblical chronological framework (Grayson 1983), though it had little bearing on the particular question of the peopling of Britain. Brixham Cave, in Devonshire, was the site that convinced members of the Royal Society that humans coexisted with extinct animals, meaning that humans had been in Britain long before any postulated Celtic migrations, but British ethnologists simply accommodated these early Britons within the notion of preCeltic Allophylians. For John Evans, Joseph Prestwich, and others who studied the Brixham stone tools 'from an antiquarian rather than a geological point of view', the tools were viewed as pre-Celtic, while 'the so-called Celtic period' was seen as coming later, with the introduction of polished stone tools and more advanced technologies (Prestwich 1860, 58-9). British ethnologists, then, could continue their research programme with little change. For example, Wilson's model of the peopling of Britain in his 1863 edition of Prehistoric Annals of Scotland differed little from that of 1851 , except that he allowed for much longer periods of prehistoric occupation $(1863,287)$.

Lubbock's Pre-Historic Times was a landmark volume for many reasons. It set out to establish prehistoric archaeology as a discipline, it coined the word 'Palaeolithic' to describe the early period of the Stone Age, it incorporated evolutionary ideas into the three-age framework, and it drew extensively on ethnographic parallels to illustrate human technological development. Its discussion of the three ages and the peopling of Europe, however, shows a great deal of continuity with the craniological ethnology that developed in the previous 20 years. The first six chapters of the book amounted to an extended argument for using the three-age system as an ethnological tool. This was the first such argument to appear in print since Thomsen's and Worsaae's frankly cursory arguments for the system were translated in the late 1840 s.

Lubbock's argument for the three-age system revolved around the existence of the Bronze Age, which he supported with 'the testimony of the most ancient writers' as well as 'the evidence of the objects themselves', which were almost always found in caches segregated by type of metal $(1865,3-4)$. He further supported the notion of a separate Bronze Age with the observation: 


\section{M. Morse CRAnIOlOGy \& THE ADOPTION OF THE 3-AGE SYSTEM IN BRITAIN}

The handles of the bronze swords are very short, and could not have been held comfortably by hands as large as ours, a characteristic much relied on by those who attribute the introduction of bronze into Europe to a people of Asiatic origin. (1865, 19)

Lubbock devoted the second chapter of Pre-Historic Times to a discussion of the Stone-Bronze transition and interpreted the Bronze Age as an intrusion of a possibly Indo-European race. Like Prichard, Wilson, Davis, and Thurnam, he thought the resolution of the question of which races corresponded to the different ages depended on the further collection of crania:

The form of the head would also be very instructive; but owing to the unfortunate habit of burning the dead which prevailed at that period, we have, as yet, very few skulls which can safely be referred to the Bronze age, and, on the whole, we must admit that, for the present, the evidence is not sufficient to justify us in expressing any very definite opinion as to the source of the Bronze age civilization. $(1865,49)$

Once he had established the existence of a Bronze Age, Lubbock could argue persuasively that stone assemblages were not simply the tools of poor or primitive people, but dated to an earlier technological age and to 'ruder races of men' $(1865,60)$. He began his discussion of Stone Age peoples with an examination of their grave-goods and modes of interment. He seems to have seen this as an incomplete and outdated method, however, and looked to skeletal evidence:

Eventually, no doubt, the human remains themselves, and especially the skulls, will prove our best guides; but at present we do not possess a sufficient number of trustworthy descriptions or measurements, to justify us in drawing any generalisation from them, excepting, perhaps, this, that the skulls found with bronze in some cases closely resemble those discovered in graves containing only stone implements; from which we may infer that, even if the use of bronze was introduced by a new and more civilised race, the ancient inhabitants were probably not altogether exterminated. $(1865,98)$

Whether the Bronze Age for Lubbock represented a complete replacement or merely the intrusion of new people, he generally followed the Scandinavian model of the three ages, in which the Celts arrived at the end of the Stone Age. He qualified this model, however, with appeals to more evidence and by offering the possibility that there were many different races during the long and apparently varied Stone Age:

As regards the pre-historic races of men we have as yet derived but little definite information from the examination of tumuli. The evidence, however, appears to show that the Celts were not the earliest colonisers of Northern Europe. Putting on one side the mysterious 'kumbecephalic' skulls [identified by Wilson] which have been already alluded to (p. 90), the men of the Stone age in Northern Europe appear to have been brachycephalic in a very marked degree, and to have had heavy, overhanging brows. Many ethnologists are inclined to believe that the Turanian race, now represented in Europe by the Fins, Lapps, and probably the Basques, once occupied the greater part of our continent, which was, however, even before the beginning of history, wrested from them by the Celts and the Teutons. $(1865,116-7)$

\section{AFTER LUBBOCK}

For the balance of the 19th century there was a growing interest in the kind of artefact-based research initiated by Thomsen. The study of artefact style led to an alternative way of defining race. Past peoples like the Celts could be defined by certain art styles or artefact types, rather than by head shapes. Yet the physiological racial sequencing conducted by the first generation of British researchers who used the threeage system continued to be central to archaeological investigations at least until the turn of the century.

John Evans was among the first archaeologists in Britain to treat archaeological objects, rather than the races behind them, as his primary subject of research. His work resulted in a trilogy of comprehensive volumes on numismatics (1864), objects of stone (1872), and objects of bronze (1881). It is only with these books that Thomsen's usage of the three-age system can be said to have reached Britain. Though Evans did not relate the three ages to particular prehistoric peoples, he retained the belief that the suddenness of the transitions indicated the arrival of new races. Joseph Anderson, the Keeper of the Museum of the Society of Antiquaries of Scotland, used the Rhind Lectures to examine the 'culture' of the various ages through the study of ornament (1883; 1886). This kind of analysis was also reflective of Thomsen's interests. 
While Evans concerned himself almost exclusively with objects and Anderson and his colleagues in Scotland tried to define culture through ornament, W. Boyd Dawkins sought to combine 'the results of osteological enquiry with those of ethnology, history, and geography' $(1880,309)$ to establish a racial sequence based on the three ages. Here, he echoed Wilson's results, arguing that an Iberic race, related to the non-Indo-European Basques, inhabited Britain in the Neolithic and were replaced by the 'tall, round- or broad-headed Celts,' who entered Europe in the Bronze Age 'composing the van of the great Aryan army' (Ibid., 343). For the Iron Age, however, Dawkins argued that there was no racial transition (Ibid., 496).

As archaeologists like Dawkins strove to integrate the results of physical anthropology into the three ages, there was a flurry of new anthropological work. The barrow-digger William Greenwell (1877) followed Thurnam's theory associating long barrows with long skulls and round barrows with round skulls and applied it to skulls he excavated in Yorkshire. In a climate of increasing specialisation, Greenwell left the detailed craniological analysis to George Rolleston, who was trying to establish the study of anthropology at Oxford (Stocking 1987, 263-4). Rolleston confirmed Thurnam's results and stressed the importance of conducting surveys of modern peoples to get a better picture of what distinguished the various races $(1877,678)$.

In the late 19th century, there was a growing enthusiasm for anthropological surveys in order to supplement information gleaned from ancient skulls. Wilson's work on hat sizes was a small example of what would become a major scientific undertaking. In the early 1850s, John Beddoe (1855) had proposed a study of the geographic spread of different hair and eye colours as a way to establish racial types. His work grew into a massive survey of physical types in the British Isles in which he hoped, like Wilson, to use living heads and complementary observations to help sort out disagreements about the races of archaeologically recovered skulls $(1885,6)$. Along with A.C. Haddon and Francis Galton, Beddoe used the British Association to enlist interested researchers to undertake a grand anthropological survey of the British Isles. By the end of the century, this survey proved impractical, but its failure to produce answers to the question of Britain's racial history did not diminish faith in the potential of physical anthropology to provide such answers someday (Urry 1984).
The failure of the British survey echoed failures to isolate craniological types on the Continent (Massin 1996). The confidence expressed by early proponents of the three-age system that further collections of skulls would solve the question of which races lived during each of the three ages was finally defeated by large collections of skulls not producing the desired results. Yet the notion that archaeological material held the answers to the racial sequence of the three ages survived well into the 20th century. To some extent the study of art and artefact style picked up where the search for skull types failed, as the idea of culture replaced the old label of race. The ideas that reached British archaeology during the spread of the three-age system within the ethnological science of the 1840 s proved more enduring than the craniology which formed the system's initial context.

\section{BIBLIOGRAPHY}

Anderson, J. 1883. Scotland in Pagan Times: The Iron Age. Edinburgh: David Douglas.

Anderson, J. 1886. Scotland in Pagan Times: the Bronze and Stone Ages. Edinburgh: David Douglas.

Anonymous. 1848. Proceedings of the annual meeting. Journal of the British Archaeological Association 3, 155.

Anonymous. 1850. 'Inquiry into the evidence of the existence of primitive races in Scotland prior to the Celtae' by Mr. D. Wilson. Athenaeum Aug. 24 (1191), 907-8.

Ash, M. 1981. 'A fine, genial, hearty band': David Laing, Daniel Wilson and Scottish archaeology. In A.S. Bell (ed.), The Scottish Antiquarian Tradition: essays to mark the bicentenary of the Society of Antiquaries of Scotland and its museum, 1780-1980, 86-113. Edinburgh: John Donald.

Bateman, T. 1848. Vestiges of the Antiquities of Derbyshire and the Sepulchral Usages of Its Inhabitants from the Most Remote Ages to the Reformation. London: J.R. Smith.

Bateman, T. 1855. A Descriptive Catalogue of the Antiquities and Miscellaneous Objects Preserved in the Museum of Thomas Bateman at Lomberdale House, Derbyshire. Bakewell.

Bateman, T. 1861. Ten Years' Diggings in Celtic and Saxon Grave Hills, in the Counties of Derby, Stafford, and York, from 1848 to 1858 . London: J.R. Smith.

Beddoe, J. 1855. On the ancient and modern ethnography of Scotland. Proceedings of the Society of Antiquaries of Scotland 1, 243-57.

Beddoe, J. 1885. The Races of Britain: a contribution to the anthropology of Western Europe. London: Trübner.

Bibby, G. 1956. The Testimony of the Spade. New York: Alfred A. Knopf. 


\section{M. Morse CRANIOLOGY \& THE ADOPTION OF THE 3-AGE SYSTEM IN BRITAIN}

Combe, G. 1843. A System of Pbrenology, vol. 2, 5 edn. Edinburgh: MacLachlan Stewart.

Cooter, R. 1989. Phrenology in the British Isles: an annotated, historical bibliography and index. Metuchen \& London: Scarecrow Press

Croker, T.C. 1847. Antiquities discovered in Orkney, the Hebrides, and Ireland, compared. Journal of the British Archaeological Association 2, 328-33.

Daniel, G. 1950. A Hundred Years of Archaeology. London: Duckworth.

Davis, J.B. 1855. On the forms of the crania of the ancient Britons. Report of the Twenty-Fourth Meeting of the British Association for the Advancement of Science, 127-8.

Davis, J.B. 1856. On some of the bearings of ethnology upon archaeological science. Archaeological Journal 13, 315-27.

Davis, J.B., \& Thurnam, J. 1865. Crania Britannica, 2 vols. London.

Dawkins, W. Boyd. 1880. Early Man in Britain and His Place in the Tertiary Period. London: Macmillan.

Dorson, R.M. 1968. The British Folklorists: a history. Chicago: University Press.

Du Noyer, G.V. 1847. On the classification of bronze celts. Archaeological Journal 4, 1-6.

Evans, J. 1956. A History of the Society of Antiquaries. Oxford: University Press.

Evans, J. 1864. The Coins of the Ancient Britons. London: J. R. Smith.

Evans, J. 1872. The Ancient Stone Implements, Weapons, and Ornaments, of Great Britain. London: Longmans.

Evans, J. 1881. The Ancient Bronze Implements, Weapons, and Ornaments, of Great Britain and Ireland. London: Longmans.

Goyder, D.G. (ed.). 1845. The Phrenological Almanac and Psychological Annual. Glasgow: Goyder.

Gräslund, B. 1987. The Birth of Prehistoric Chronology: Dating Methods and Dating Systems in NineteenthCentury Scandinavian Archaeology. Cambridge: University Press.

Grayson, D.K. 1983. The Establishment of Human Antiquity. New York: Academic Press.

Greenwell, W. 1877. British Barrows: A Record of the Examination of Sepulchral Mounds in Various Parts of England. Oxford: Clarendon Press.

Hoare, R. Colt. 1812. The Ancient History of Wiltshire, vol. 1. London: William Miller.

Hoare, R. Colt. 1821. The Ancient History of Wiltshire, vol. 2. London: Lackington \& Co.

Hodgkin, T. 1850. Obituary of Dr. Prichard. Journal of the Ethnological Society of London 2, 182-207.

Hunt, J. 1868. Knox on the Celtic race. Anthropological Review 6, 175-91.

King, R. 1850. Address to the Ethnological Socicty of London. Journal of the Ethnological Society of London 2, $9-40$.

Klindt-Jensen, O. 1975. A History of Scandinavian Archaeology. London: Thames \& Hudson.
Knox, R. 1850. The Races of Men: a fragment. London: Renshaw.

Lubbock, J. 1865. Pre-Historic Times, As Illustrated by Ancient Remains, and the Manners and Customs of Modern Savages. London and Edinburgh: Williams \& Norgate.

Marsden, B.M. 1983. Pioneers of Prebistory: leaders and landmarks in English archaeology (1500-1900). Lancashire: Hesketh.

Massin, B. 1996. From Virchow to Fischer: Physical anthropology and 'modern race theories' in Wilhelmine Germany. In G.W. Stocking, Jr (ed.), Volksgeist as Method and Ethic: essays on Boasian ethnography and the German anthropological tradition, 79-154. Madison: University of Wisconsin Press.

Nilsson, S. 1838-43. Skandinaviska Nordens Ur-invånare, ett försök $i$ komparativa ethnografien och ett bidrag till menniskoslägtets utvecklings-historia. Lund.

Nilsson, S. 1848. On the primitive inhabitants of Scandinavia. Report of the Seventeenth Meeting of the British Association for the Advancement of Science, 31-2. Trans. Norton Shaw.

Nilsson, S. 1868. The Primitive Inhabitants of Scandinavia, 3 edn. J. Lubbock (ed.). London: Longmans.

Prestwich, J. 1860. On the occurrence of flint-implements, associated with the remains of extinct mammalia, in undisturbed beds of a late geological period. Proceedings of the Royal Society of London 10, 50-9.

Prichard, J.C., 1813. Researches into the Physical History of Man. London: Arch.

Prichard, J.C. 1826. Researches into the Physical History of Mankind, 2 edn, 2 vols. London: Arch.

Prichard, J.C. 1841. Researches into the Physical History of Mankind, vol. 3: Containing researches into the history of the European nations, 3 edn. London: Sherwood \& Co.

Prichard, J.C. 1843. The Natural History of Man. London: Bailliere.

Prichard, J.C. 1844. On the crania of the Laplanders and Finlanders. Proceedings of the Zoological Society of London 12, 129-35.

Prichard, J.C. 1848. On the various methods of research which contribute to the advancement of ethnology, and the relations of that science to other branches of knowledge. Report of the Seventeenth Meeting of the British Association for the Advancement of Science, 230-53.

Retzius, A. 1847. On the ethnographical distribution of round and elongated crania. Report of the Sixteenth Meeting of the British Association for the Advancement of Science, 116.

Richards, E. 1989. The 'moral anatomy' of Robert Knox: The interplay between biological and social thought in Victorian scientific naturalism. Journal of the History of Biology 22(3), 373-436.

Rolleston, G. 1877. General remarks upon the series of prehistoric crania. In W. Greenwell, British Barrows: a record of the examination of sepulchral mounds in various parts of England, 557-750. Oxford: Clarendon Press. 
Royal Society of Northern Antiquaries. 1836. Report Addressed by the Royal Society of Northern Antiquaries to Its British and American Members. Copenhagen.

Royal Society of Northern Antiquaries. 1848. Guide to Northern Archaeology. Earl of Ellesmere (ed.). London: Bain.

Stepan, N. 1982. The Idea of Race in Science: Great Britain 1800-1960. London: Macmillan.

Stocking, G.W., Jr. 1973. From chronology to ethnology: James Cowles Prichard and British anthropology. In G.W. Stocking, Jr (ed.), Researches into the Physical History of Man, ix-cx. Chicago: University Press.

Stocking, G.W., Jr. 1987. Victorian Anthropology. New York: Free Press.

Thoms, W.J. 1846. Review of Danemark's Vorzeit Durch Altherthumer und Grabhugel Beleuchtet von J.J.A. Worsaae 1844. Archaeological Journal 2, 291-2.

Thomsen, C.J. 1836. Ledetraad til Nordisk Oldkyndighed. Copenhagen.

Thurnam, J. 1850. On Danish tumuli, and importance of preserving crania found in tumuli. Archaeological Journal 7, 34-5.

Thurnam, J. 1865. On the two principal forms of ancient British and Gaulish skulls. Memoirs Read Before the Anthropological Society of London 1, 120-68, 459-519.

Trigger, B.G. 1989. A History of Archaeological Thought. Cambridge: University Press.

Urry, J. 1984. Englishmen, Celts, and Iberians: The ethnographic survey of the United Kingdom, 1892-1899. In G.W. Stocking, Jr (ed.), Functionalism Historicized: essays on British social anthropology, 83-105. Madison: University of Wisconsin Press.

Van Riper, A.B. 1993. Men among the Mammoths: Victorian science and the discovery of human prehistory. Chicago: University Press.

Wilde, W.R. 1840. Narrative of a Voyage to Madeira, Teneriffe, and along the Shores of the Mediterranean, Including a Visit to Algiers, Egypt, Palestine, Tyre, Rhodes, Telmessus, Cyprus, and Greece. Dublin: Curry \& Co.

Wilde, W.R 1844. The ethnology of the ancient Irish. Dublin Literary Journal 2, 231-4, 247-51.

Wilde, W.R. 1849. The Beauties of the Boyne, and its Tributary, the Blackwater. Dublin: McGlashan.
Wilde, W.R. 1857. A Descriptive Catalogue of the Antiquities of Stone, Earthen, and Vegetable Materials, in the Museum of the Royal Irish Academy. Dublin: Gill.

Wilde, W.R. 1861. A Descriptive Catalogue of the Antiquities of Animal Materials and Bronze in the Museum of the Royal Irish Academy. Dublin: Hodges \& Co.

Wilkins, J. 1961. Worsaae and British antiquities. Antiquity $35,214-20$.

Wilson, D. 1849. Synopsis of the Museum of the Society of Antiquaries of Scotland. Edinburgh.

Wilson, D. 1851a. The Archaeology and Prehistoric Annals of Scotland. Edinburgh: Sutherland \& Knox.

Wilson, D. 1851b. Inquiry into the evidence of the existence of primitive races in Scotland prior to the Celtae. Report of the Twentieth Meeting of the British Association for the Advancement of Science, 142-6.

Wilson, D. 1863. Prehistoric Annals of Scotland, 2 edn, 2 vols. London: Macmillan.

Wilson, D. 1865. Inquiry into the physical characteristics of the ancient and modern Celt of Gaul and Britain. Anthropological Review 3, 52-84.

Worsaae, J.J.A. 1843. Danmarks Oldtid oplyst ved Oldsager og Gravhøie. Copenhagen.

Worsaae, J.J.A. 1847a. An account of the formation of the museum at Copenhagen, and general remarks on the classification of antiquities found in the North and West of Europe. Proceedings of the Royal Irish Academy 3, $310-15,327-44$.

Worsaae, J.J.A. 1847b. A few remarks upon the antiquities of silver found at Cuerdale. Archaeological Journal 4, 200-3.

Worsaae, J.J.A. 1849. The Primeval Antiquities of Denmark. London: Parker. Trans. W.J. Thoms.

Wright, T. 1852. The Celt, the Roman, and the Saxon: a bistory of the early inhabitants of Britain, down to the conversion of the Anglo-Saxons to Christianity. London: Hall \& Co.

Wright, T. 1855 . On the early ethnology of Britain. Report of the Twenty-Fourth Meeting of the British Association for the Advancement of Science, 130. 